УДК 677.021.15/18:677.12

А.С. ТІХОСОВ, Н.В. НЕЖЛУКЧЕНКО

Херсонський національний технічний університет

Н.П. ЛЯЛІНА

Київський національний університет будівницттва і архітектури

\title{
СПОЖИВНІ ХАРАКТЕРИСТИКИ КОНОПЛЯНИХ ВОЛОКОН ОДЕРЖАНИХ 3 ТРЕСТИ РІЗНИХ СПОСОБІВ ПРИГОТУВАННЯ
}

\author{
А.С. ТИХОСОВ, Н.В. НЕЖЛУКЧЕНКО
}

Херсонский национальный технический университет

Н.П. ЛЯЛИНА

Киевский национальный университет строительства и архитектуры

ПОТРЕБИТЕЛЬСКИЕ ХАРАКТЕРИСТИКИ КОНОПЛЯНЫХ

ВОЛОКОН ПОЛУЧЕННЫХ С ТРЕСТЫ РАЗНЫХ СПОСОБОВ

ПРИГОТОВЛЕНИЯ

A. TIHOSOV, N. NEGLUKCHENKO

Kherson national technical university

N. LYLINA

Kyiv national university of civil engineering and architecture

\section{CONSUMER CHARACTERISTICS OF HEMP FIBERS RECEIVED FROM} THREE DIFFERENT METHODS OF PREPARATION

\section{https://doi.org/10.36910/6775-2310-5283-2020-13-19}

Мета. Визначення основних споживних характеристик конопляних волокон одержаних з трести різних способів призначення, від яких залежить сфера їх застосування для виготовленні товарів технічного та побутового призначення.

Методика. Розривне навантаження (міџність), гнучкість та лінійна щільність волокон визначали за стандартними методиками, які наведені у ГОСТ 23087-78 та ГОСТ 10379-76. На даний час нові стандарти на конопляні волокна, які розроблені Інститутом луб'яних культур НААН Украӥни, не затверджені Держстантартом, тому були використані методики стандартів СРСР.

Результати. За оцінкою основних споживних характеристик конопляних волокон, які отримані з трести різних способів приготування, визначені сфери застосування конопляних волокон для одержання кручених виробів, канатів, вірьовок, шпагатів та текстильних товарів широкого вжитку.

Наукова новизна. Вперше визначені споживні характеристики волокон конопель, які виділені з трести після різних способів обробки стебел соломи. На основі ичи 
характеристик розроблені рекомендації щзодо подальшого застосування волокон для виготовлення різноманітного асортименту товарів широкого вжитку.

Практична значимість. Проведені дослідження дають можливість спрогнозувати застосування оптимального способу одержання трести конопель для виготовлення товарів иільового призначення.

Ключові слова: стебла соломи конопель, треста, споживні характеристики, розривне навантаження, лінійна щуільність, гнучкість, кручені вироби, тканини.

\section{Постановка проблеми у загальному вигляді та її зв'язок із} важливими науковими чи практичними завданнями. За фізикомеханічними та санітарно-гігієнічними властивостями, які детально висвітлені у відомих монографіях українських вчених Інституту луб’яних культур НААН та Херсонського національного технічного університету [1-3], конопляне волокно займає першорядне місце серед натуральних волокон таких як бавовна, льон, рамі, кенаф та джут. Традиційно в Україні конопляне волокно використовували в канатно-шпагатному виробництві, для технічних цілей для виготовлення каболки, мішковини, канатів, вірьовок, шпагату.

В той час у Європейських країнах, Китаї та Північній Америці [4] конопляне волокно має більш широке застосування для одержання цінних паперів, композиційних матеріалів та тканин. За допомогою інноваційних технологій, які використовуються в цих країнах, конопляні волокна набувають специфічних споживних властивостей, що дозволяє розширити сферу їх застосування. В Україні вузьке застосування конопляних волокон пояснюється недосконалістю технологій переробки стебел соломи конопель. Для розширення сфери застосування цих волокон необхідно розробляти технології, які забезпечать одержання волокна 3 визначеними споживними характеристиками, зокрема, високим розривним навантаженням, заданою лінійною щільністю, гнучкістю, штапельною довжиною. Ці показники визначають подальше цільове застосування волокон для виробництва товарів різноманітного призначення.

Визначальним етапом в процесі виділення волокна зі стебел конопляної соломи, від якого в значній мірі залежать споживні характеристики волокна, $є$ процес приготування трести, тобто перетворення стебел соломи конопель в тресту. На даний час існує чотири способи одержання трести: це холодноводне мочіння (ХВM), розстил стебел соломи в природних умовах $(\mathrm{P})$, пропарювання (П) та весняне збирання стебел соломи (В). Усі ці способи можуть бути удосконалені. В наукових дослідженнях способів приготування трести конопель наведені несистематизовані, а лише окремі споживні 
характеристики волокна, які не дозволяють встановити застосування способу приготування трести для одержання волокна цільового призначення. Тому в даній роботі основним завданням було визначити споживні характеристики волокон конопель, які отримують після застосування існуючих способів одержання трести із стебел соломи технічних конопель.

Аналіз останніх досліджень, у яких започатковано вирішення проблеми. В роботах Інституту луб'яних культур НААН України розроблено нові й удосконалено існуючі способи приготування трести конопель холодноводним мочінням, розстилом на полі та пропарюванням [5]. Так, Жуплатовою Л.М., Кузьменко Л.О. та Пашиним Є.М. за допомогою удосконалення режиму пропарювання стебел соломи конопель [6-8] було підвищено міцність конопляного волокна на 9,4-10,7 дан та зменшена його лінійна щільність від 51,7-35,9 текс.

Зарубіжні вчені [9-11] досліджували якість конопляних волокон, в основному, залежно від механічної обробки стебел конопель, а вплив способів приготування трести на споживні характеристики волокон в наведених роботах не розглядався.

Аналіз відомих наукових робіт в області переробки та застосування волокон конопель свідчать про те, що, в основному, дослідження були направлені на удосконалення режимів приготування трести без детального аналізу впливу зміни технологій на споживні характеристики волокон з метою розробки рекомендацій 3 подальшого використання одержаних волокон в створені товарів широкого вжитку.

Цілі статті. Визначення споживних характеристик волокон конопель, які виділені після різних способів одержання трести, 3 метою їх цільового застосування для виробництва товарів різного функціонального призначення.

Об’єкт дослідження. Об’єктом дослідження $є$ товари різного функціонального призначення із конопляних волокон, які виділені після різних способів одержання трести.

Методи дослідження. Тресту одержували зі стебел соломи безнаркотичних конопель сорту Гляна за чотирма традиційними способами: холодноводним мочінням, пропарюванням, розстиланням та весняним збиранням стебел соломи. Холодноводне мочіння та пропарювання стебел соломи виконували в лабораторних умовах, а розстилання - у польових умовах, холодноводне мочіння проводили за температури $20 \pm 1{ }^{0} \mathrm{C}$ і терміні замочування 16 діб. Пропарювання стебел соломи здійснювали за температури $150{ }^{0} \mathrm{C}$ і тиску в автоклаві 250 кПа. Розстилання в польових 
умовах відбувалося в серпні за середньодобової температури $25{ }^{0} \mathrm{C}$ на дослідних ділянках Інституту зрошувального землеробства НААН України. Термін вилежування стебел трести конопель становив 30 діб. Весняне збирання трести здійснювалось на дослідних ділянках Інституту луб'яних культур НААН України. Одержану тресту переробляли механічним способом на Лютенському пенькозаводі Полтавської області.

Виклад основного матеріалу дослідження 3 повним обгрунтуванням отриманих наукових результатів. Після механічної переробки трести, яка була одержана за холодноводним мочінням (XBM), розстилом (Р), пропарюванням (П) та після весняного збирання стебел соломи сорту Гляна (B), було отримано волокно. За стандартними методиками визначені його основні споживні характеристики: гнучкість, міцність та лінійна щільність. Результати наведені в таблиці 1.

Таблиця 1

Споживні характеристики конопляних волокон виділених з трести різних способів приготування

\begin{tabular}{|l|c|c|c|}
\hline \multirow{2}{*}{$\begin{array}{c}\text { Способи приготування } \\
\text { трести }\end{array}$} & \multicolumn{3}{|c|}{ Споживні характеристики волокна } \\
\cline { 2 - 4 } & гнучкість, мм & міцність, даН & лінійна щільність, текс \\
\hline $\begin{array}{l}\text { Холодноводне мочіння, } \\
\text { ХВМ }\end{array}$ & 27,4 & 22,6 & 20,4 \\
\hline Розстил, Р & 24,7 & 18,1 & 26,5 \\
\hline Пропарювання, П & 13,7 & 34,6 & 35,9 \\
\hline Весняне збирання, В & 14,3 & 10,2 & 37,6 \\
\hline
\end{tabular}

Аналіз даних таблиці 1 дає можливість встановити, що волокно, отримане після пропарювання стебел соломи, є найміцнішим, має найнижче значення гнучкості та найвище значення лінійної щільності. В процесі механічної переробки трести після пропарювання видаляється тільки невелика кількість хімічних речовин, які легко розчиняються у воді. Основна кількість колоїдних речовин, яка залишається на стеблах, набухає і переходить у форму лігніноподібних клеїв, тому для очищення волокна застосовується жорсткі режими механічного оброблення трести 3 числом оборотів тіпальних барабанів 115-125 об/хв. замість 100-110 об/хв. та понижених значеннях вологості 10-11\% замість 12-14\%. У зв'язку з цим, основним недоліком волокна конопель після пропарювання $є$ його підвищена жорсткість, що відображається на втраті гнучкості. Таке волокно не доцільно використовувати в прядильному виробництві для одержання текстильних 
виробів. Але волокна після пропарювання мають підвищену міцність, що дозволяє рекомендувати таке волокно для одержання канатів, шпагатів та інших кручених виробів. Окрім того, як було раніше доказано, волокно після пропарювання стійке до гниття [12], втрата його міцності при виробничих випробуваннях канатів впродовж 30 днів складає всього $15 \%$, в той час при випробуваннях канатів, які виготовлені 3 волокна після холодноводного мочіння, втрата міцності складає $75 \%$.

Після холодноводного мочіння треста легко розділяється на волокно i деревину, яка легко відділяється від волокна механічним шляхом. Відділене волокно має найвищі показники гнучкості 27,4 мм, найнижчі показники лінійної щільності 20,4 текс. Таке волокно може бути застосоване у прядильному виробництві, для виготовлення тканин.

Аналогічні результати одержані при аналізі волокон після розстилу стебел на полі, але в цьому випадку зменшується міцність волокон на 4,5 даН, порівняно 3 волокном після холодноводного мочіння. Тобто волокно після розстилу при переробці його у прядильному виробництві матиме підвищену обривність.

Найнижчі споживні характеристики має волокно, яке отримується після весняного збирання трести. Це волокно має найнижчу міцність 10,2 даН, гнучкість 14,3 мм та найвищу лінійну щільність 37,6 текс. Такі споживні характеристики волокон можуть забезпечити застосування його у будівництві та для виготовлення композиційних матеріалів як природних наповнювачів, а також у целюлозно-паперовому виробництві.

На основі виробничих випробувань конопляних волокон, які виділені 3 трести після різних способів приготування, розроблені рекомендовані сфери застосування конопляних волокон, які подано в таблиці 2.

Таблиця 2

\section{Рекомендовані сфери застосування конопляних волокон, одержаних} після різних способів приготування трести

\begin{tabular}{|c|c|c|c|}
\hline \multicolumn{4}{|c|}{ Способи приготування трести } \\
\hline $\begin{array}{l}\text { Холодноводне } \\
\text { мочіння, ХВМ }\end{array}$ & Розстил, Р & Пропарювання, П & Весняне збирання, В \\
\hline $\begin{array}{l}\text { Тканини, } \\
\text { трикотажні вироби, } \\
\text { шкарпетки, } \\
\text { галантерейні вироби, } \\
\text { взуття }\end{array}$ & $\begin{array}{c}\text { Тканини, } \\
\text { трикотажні вироби, } \\
\text { шкарпетки, } \\
\text { галантерейні } \\
\text { вироби, } \\
\text { взуття }\end{array}$ & $\begin{array}{c}\text { Канати, } \\
\text { шпагати, мішковина, } \\
\text { вірьовки, } \\
\text { каболка }\end{array}$ & $\begin{array}{c}\text { Целюлоза, } \\
\text { пакля, } \\
\text { неткані матеріали, } \\
\text { технічних текстиль, } \\
\text { наповнювачі для } \\
\text { композиційних } \\
\text { матеріалів }\end{array}$ \\
\hline
\end{tabular}


Висновки та перспективи подальших досліджень. 3 проведених досліджень можна зробити висновок: для виготовлення товарів, які мають високу стійкість до гниття i можуть бути використані для виготовлення швартовочних канатів, необхідно застосовувати волокно, яке отримане після пропарювання стебел трести, що підтверджено при використанні паренцевого конопляного волокна на Харківському канатному заводі. Одержані канати мали розмір по периметру 65,2-77,8 мм, міцність 2983-3191 даН, розривна довжина 6,4-8,0 км.

Споживні характеристики волокон, які отримані 3 трести після холодноводного мочіння та розстилу, мають підвищену гнучкість та найнижчу лінійну щільність, тому вони найбільш придатні для виготовлення текстильних виробів, трикотажу та шкарпетно-галантерейних виробів. Середній номер пряжі, яка отримана з волокна після холодноводного мочіння, 0,26-0,27, добротність 13,4-16,4 км, число обривів 44,0-51,7 вер/год.

Показники пряжі, яка отримана із конопляного волокна після розстилу стебел конопель на полі, мають номер 0,28-0,30, добротність 12,3-13,0 км, число обривів 60,5-71,4 вер/год. Тобто якість пряжі у цьому випадку нижча, порівняно з пряжею, яка отримана із волокна після холодноводного мочіння.

\section{Список використаних джерел}

1. Коноплярство: наукові здобутки і перспективи: монографія / [Вировець В.Г., Лайко I.М., Мигаль М.Д., Коропченко С.П. та ін.]; за ред.. I.О. Маринченка, Guo Chunjing. Суми: ФОП Щербина I.B., 2018. 158 с.

2. Клевцов К.М., Гілязетдінов Р.Н., Круглий Д.Г. Технології збирання та комплексної переробки лубоволокнистих рослин: [монографія]. Херсон: ХНТУ, 2015. 414 с.

3. Чурсіна Л.А., Богданова О.Ф., Ляліна Н.П., Резвих Н.І. Товарознавство i стандартизація продукції безнаркотичних конопель: [монографія]. Херсон: ПП Вишемирський В.С. 2012. 308 с.

4. Engineering sciences: development prospects in countries of Europe at the beginning of the third millennium: Collective monograph. Volume 2. Riga: Izdevnieciba "Baltija Publishing", 2018. 492 p. // Коропченко С.П., Мохер Ю.В. Підсумки науково-дослідних робіт 3 механічної переробки конопель на підприємствах малого та середнього бізнесу $-112 \mathrm{c}$.

5. Жуплатова Л.М. Прогресивні технологічні прийоми приготування трести конопель. Збірник наукових пращь інституту луб'яних культур НААН. 2007. Випуск 4. С. 221.

6. Жуплатова Л.М., Кузьменко Л.О. Об использовании химических реагентов в процессе приготовления паренцовой тресты. Селекция, семеноводство, уборка и первичная обработка конопли: сб. науч. трудов. 1990. С. 55-58.

7. Жуплатова Л.М., Кузьменко Л.О. Оптимизация режима замочки соломы конопли в процес се пропаривания. Технология воздельввания и обработки конопли: сб. науч. трудов. Глухов: ВНИИЛК, 1991. С. 64-68. 
8. А.c. 1680812 СССР, МКИ D 01 C 1102 Способ получения тресты из соломы конопли / Л.М. Жуплатова, Е.Л. Пашин, Л.О. Кузьменко (СССР). № 46193833/12; Заявлено 12.12.88; Опубл. 30.09.91; Бюл. № 36. - 2 с.

9. Hocman M. Flax, hemp and allied fibers in the Czech. Euroflax. 2003. № 2. P. 4-5.

10. Dir A. European Subsidy for the Cultivation of Flax and Hemp. Euroflax Newsletter. Poznan, Poland. 2002. № 1 (17). P. 22.

11. Robert Evans, Ross H. Wearne, Adrian F.A. Wallis. CEH bleached radiatapine bisulfate pulp as a sourse of chemical cellulose. Appita. 1990. V.43, № 2. P.130-136.

12. Лунев И.Я., Медведева М.Г. Усовершенствованные способы приготовления льняной и конопляной тресты: Курс лекций. Москва: Из-во Легкая индустрия, 1971. 48 с.

\section{References}

1. Virovets V.G., Lajko I.M., Migal M.D., Koropchenko S.P. etc. (2018). Hemp farming: scientific achievements and prospects: monograph. Sums: FOP Shcherbina IV. 158 p.

2. Klevtsov KM, Gilyazetdinov R.N., Krugly D.G. (2015). Technologies of harvesting and complex processing of tubers. Kherson: KhNTU. 414 p.

3. Chursina L.A. (2012). Merchandising and standardization of non-narcotic hemp products. Kherson: PE Vyshemirsky VS. 308 p.

4. Koropchenko SP, Moher Yu.V.(2018). Engineering sciences: development prospects in countries of Europe at the beginning of the third millennium: Collective monograph. Volume 2. Riga: Izdevnieciba "Baltija Publishing". Results of research works on mechanical processing of hemp at the enterprises of small and medium business. $112 \mathrm{p}$.

5. Zhuplatova L.M. (2007). Advanced Technological Techniques for the Preparation of Cannabis Trust. Proceedings of the Institute of Bast Crops of NAAS. Issue 4. P. 221.

6. Zhuplatova L.M., Kuzmenko L.O. (1990). On the Use of Chemical Reagents in the Preparation of Parental Trust. Breeding, Seeds, Harvesting and Primary Treatment of Cannabis: Sat. scientific works. - Deaf: VNIILK. P. 55-58.

7. Zhuplatova L.M., Kuzmenko L.O. (1991) Optimization of the mode of soaking of hemp straw in the process of steaming. Technology of cultivation and treatment of hemp: Sat. scientific works. Glukhov: VNIILK. P. 64-68.

8. Zhuplatova, E.L., Pashin, L.O., Kuzmenko A.S. 1680812 USSR, MKI D 01 C 102 । The method of obtaining hemp straw trusts / LM. (USSR). № 46193833/12; Declared 12.12.88; Publ. 09/30/91; Bul. № 36. - 2 p.

9. Hocman M. (2003). Flax, hemp and allied fibers in the Czech Republic. Euroflax. № 2. P. 4-5.

10. Dir A. (2002). European Subsidy for the Cultivation of Flax and Hemp. Euroflax Newsletter. Poznan, Poland. № 1 (17). P. 22.

11. Robert Evans, Ross H. Wearne, Adrian F.A. Wallis (1990). CEH bleached radiatapine bisulfate pulp as a sourse of chemical cellulose. Appita. V.43. № 2. P.130-136.

12.Lunev I.Ya., Medvedeva M.G. (1971). Improved methods for preparing flax and hemp trusts: Lecture course. Moscow: Izv. Light Industry. 48 p.

Цель. Определение основных потребительских характеристик конопляных волокон полученных из тресты разных способов приготовления, от которых зависит сфера применения их при производстве товаров технического и бытового назначения.

Методика. Для волокон, полученных из тресты после холодноводной мочки, биологического расстила на поле, пропаривания и весенней уборки стеблей соломь конопли определялись: разрывная нагрузка (прочность), гибкость и линейная плотность по 
стандартным методикам, приведенным в ГОСТ 23087-78 и ГОСТ 10379-76. Новые стандарты в данное время, которые разработаны Институтом лубяных культур НААН Украины не утверждены Госстандартом, поэтому были использованы методики стандартов СССР.

Результаты. По оиенке основных потребительских характеристик конопляных волокон, полученных из тресты разных способов приготовления определены сферы использования конопляных волокон для получения крученых изделий канатов, веревок, шпагатов и текстильных товаров широкого назначения.

Научная новизна. Впервые определены потребительские характеристики волокон из конопли, полученных после разных способов обработки стеблей соломы, на основе которых разработаны рекомендачии по дальнейшему использованию волокон для изготовления разнообразного ассортимента товаров широкого назначения.

Практическая значимость. Проведенные исследования дают возможность прогнозировать применения оптимального способа получения тресты для изготовления товаров циелевого назначения.

Ключевые слова: стебли соломы конопли, треста, потребительские характеристики, разрывная нагрузка, линейная плотность, гибкость, крученые изделия, ткани.

Purpose. Determination of the basic consumption characteristics of hemp fibers obtained from trusts of different purposes, on which the scope of their application in the manufacture of technical and household goods depends.

Methodology. The fibers obtained from the reed after coldwater wetting, biological spreading in the field, steaming and spring harvesting of hemp straw stems were determined: breaking load (strength), flexibility and linear density according to standard methods given in GOST 23087-78 -76. Currently, new standards for hemp fiber, which were developed by the Institute of bast crops of the NAAS of Ukraine are not approved by the State Standard, therefore, methods of standards of the USSR were used.

Findings. According to an assessment of the main consumption characteristics of hemp fibers obtained from three hundred different methods of preparation, the scope of application of hemp fibers for the production of twisted products, ropes, ropes, twines and consumer goods is defined.

Originality. For the first time the consumption characteristics of hemp fibers isolated from the trust after different methods of processing straw stalks have been determined, on the basis of which recommendations for the further use of fibers in the manufacture of a wide range of consumer goods have been developed.

The practical value. The conducted studies make it possible to predict the use of the optimal method of obtaining hemp shakes for the manufacture of goods for the intended purpose.

Key words: stems of hemp straw, trust, consumption characteristics, breaking load, linear density, flexibility, twisted products, fabrics.

Стаття рекомендована до публікаиії доктором технічних наук, професором Херсонського НТУ Чурсіною Л.А. Дата надходження в редакиію 02.01.2020 p. 